\title{
The Particular Law of The Romanian Church United with Rome And the CCEO \\ With Reference to Divine Cult And the Sacraments. Theological And Historical Premises (XVII ${ }^{t h}-X V I I I^{t h}$ Centuries)
}

\author{
Cornel Dirle
}

\section{Introduction: fundamental assumptions}

In 1872, the first Council of the Greek-Catholic Church Province of Alba-Iulia and Fagaras took place in Blaj (CP I, further on). Out of the ten titles that form the subject of the emanated Decrees, two refer to the sacraments and the divine cult - Title V, De SS. Sacramentis, and Title VI, De Cultu Divino ${ }^{1}$. Chapter I - De Sacramentis in genere - from Title V starts with a brief presentation of the sacramental economy of redemption given to us by our Saviour: "Salvator Noster Iesus Chrisus naturae nostrae infirmitatem considerans, publicos gratiae fontes in Ecclesia iugiter manantes aperire dignatus est, atque voluit bomines corpore ac anima praeditos, qui ad spiritualia nisi per sensibililia evebuntur, dona coelestia per quaedam signa externa, quae sunt SS. Sacramenta, degustare et suscipere"; after which, in accordance with the scholastic method of defining a reality after its genre and species (definitio - divisio - distincto) follows a definitio of the sacrament in general, and a divisio with a brief description of each of the seven sacraments, further divided in Sacramenta mortuorum and Sacramenta vivorum. The provided definition - Novae Legis Sacramenta sunt signa visibilia gratiae invisibilis, quae gratiam non tantum significant, verum etiam continent et efficient reproduces with approximation another definition, put forward by Peter Lombardus $^{2}$, which has became part of the theological Western thought; but omits the mentioning of the setting up of the sacraments, though the idea is suggestively emphasized in the first part of the chapter and made more explicit several paragraphs later. The source of the definition is not

\footnotetext{
${ }^{1}$ Cf. Concilium Provinciale Primum Provinciae Ecclesiastice Greco-Catolice Alba Iuliensis et Fogarasiensis celebratum anno 1872, Blaj, 1866, p.69-101.

${ }^{2}$ Cf. Peter Lombardus, Sententiarum Liber, IV, dist.1, num.2: PL 192, 839.
} 
mentioned, as it happens in the case of other important assertions, probably because, under that form, it has not been invested with magisterial authority in any council act.

The fifth paragraph of the same chapter mentions the uneffaceable character inscribed in the soul by the sacraments of Baptism, Confirmation and Ordination ${ }^{3}$, making reference to a quotation from a homily of Saint Basil about Baptism ${ }^{4}$.

The second paragraph asserts the sacramental efficiency ex opere operato, by virtue of divine institution, for all those who do not put obstacles in its way, in a formula that implicitly refers to the $6^{\text {th }}$ and the $8^{\text {th }}$ canon concerning the Sacraments in general, of the seventh session of the Council in Trento. In the same paragraph, the capacity of the subject, the prescribed matter and form, and the legitimate minister are also mentioned as prerequisites for a valid administration of the sacrament. The following chapters (II-IX) of the same Title $\mathrm{V}$ are entitled De Sacramentis in species.

In comparison with the ideas briefly mentioned above, and in relation to our subject of interest, we should keep in mind only the definition given to the sacraments by the first canon, included in Title XVI - De cultu divino et praesertim de sacramentis, can. 667, where the ecclesiastical and the functional register emerge as relevant,, tough they are not considered as much in themselves as quoad nos: "Per sacramenta, quae Ecclesia dispensare tenetur, ut sub signo visibili mysteria Christi communicet, Dominus noster Iesus Christus homines in virtute Spiritus Sancti sanctificat, ut singulari modo Dei Patris veri adoratores fiant, eosque sibi ipsi et Ecclesiae, suo Corpori, inserit" ; as far as the vocabulary is concerned, the terms "matter", "form", and "character" do not appear in the recent Codex Canonum Ecclesiarum Orientalum (CCEO).

Another subsequent codification of specific law of this church province, as far as the cult is concerned, can be found in the decrees of the third Regional Council (CP III), held in Blaj in 1990, where, out of the four titles under which the corpus is grouped, the Title II refers to the cult of God (De cultu divino), and is further subdivided in: 1. De sancta Liturgia. 2. De aedibus sacris. 3. De coemeteriis. The first chapter starts with a reference to the first regional council (quoting from Title VI, chapter II, De cultu Divino Publico promovendo et de Sanctficatione Dierum Festorum, on the holy Liturgy as the centre of the public cult:

\footnotetext{
3 „Baptismus, Confirmatio et Ordo” in the latin text of the document, and „Botezul, Confirmatiunea [s.n] si Chirotonia" in the Romanian version of the text, p.71-72.

4 "Sigilum quod conatu nullo frangi potest”, but under the title Homilia in Sanctum Baptisma in the edition Migne PG 31, 432-444, this quotation is not included.

${ }^{5}$ We used the bilinguist edition of „Codul Canoanelor Bisericilor Rasaritene. Pro Manuscripto. Text paralele latin-român" (translated by Fr. Iuliu Muntean), Presa Universitara Clujeana, 2001.
} 
"Centrum cultus publici est in S. Liturgia verum ac proprium illudque unicum Novae Legis Sacrificium, in quo sub speciebus panis et vini Christus ipse mystice immolatur, atque Patri coelesti tamquam victima offertur in recognitionem supremi sui dominii in omnem creaturam. Quoniam igitur idem ille Christus, qui in ara Crucis cruente se obtulit, in sacra Liturgia incruente sacrificatur, idcirco per applicationem satisfactionis et meritorum in Cruce semel consummatorum boc perenne sacrificium non modo laudis est et gratiarum actionis, sed etiam propitiatorium pro vivis et defunctis, quod pro peccatis, poenis, satisfactionibus et aliis necessitatibus iuxta Apostolorum traditionem debet offerri." ${ }^{6}$. The reference is followed by a series of dispositions grouped into 13 paragraphs, concerning the dignified celebration of the Eucharistic Holy Liturgy, in accordance with the typiconal norms and the sections of the officially ${ }^{7}$ approved Ordinal, as well as the observance of the right moment of the day to be dedicated to the celebration, the non-liturgical days and the eucharistic fasting, the exceptional situation of successive celebrations on the same altar on the same day, or, as more broadly discussed in the next five paragraphs, the application of the effects of the liturgical sacrifice and the dispositions concerning the stipend of the priest.

We intend to extend the presentation of only the last two aspects mentioned above, while the argument will be continued in a following section of the article. The $9^{\text {th }}$ paragraph starts with the assertion of the sacrificial character of the Holy Liturgy, sacrificium propitiatorium ac impetratorium, besides the mentioning of the Liturgy's laudatory and gratifying aspects. It is a sacrifice where the same Christ, who has sacrificed himself by dying on the Cross, becomes both victim and priest, a reason why the Holy Liturgy can produce in an infallible way similar effects; and "if, however, he for whom the holy sacrifice is made, does not become part of the effects of that sacrifice, the situation can be explained through a lack of disposition in the respective subject, or any other reason" 8 . The second half of the same paragraph brings further details related to the positive effects of the liturgical sacrifice, by making a distinction between the general positive outcome (from which most of the participants at the Holy Liturgy benefit), the individual one (ascribed only to the priest), and the special one (middle-intermediary between the first two), received by those for whom the sacrifice was made. As a conclusion

\footnotetext{
${ }^{6}$ Concilum Provinciale Tertium Provinciae Ecclesiasticae Graeco-Catholice Alba-Iulensis et Fogarasiensis celebratum anno 1900, Blaj 1906, p. 83.

${ }^{7}$ Concerning the prescriptions of the sections, we just mention here, postponing the larger discussion of the subject for another historico-liturgical-dogmatic study, the situation of the celbrations from the 8th paragraph and the reciting, by all the participants, of all the aspects pescribed in the Ordinal, with a special attention given to the consacration, a stipulation that is not actually included in the sections of the Ordinal's editions.

${ }^{8}$ The Third regional council..., Blaj, 1906, p. 92.
} 
to the paragraph discussed so far, "the holy sacrifice is extremely useful to the Church, for which it is generally made for, to the priest who brings it, and to those for whom it is specially made" . The following paragraphs discuss the following aspects: the motivation of the limited effect of the Holy Liturgy quoad homines (no.10), the mentioning of those for whom the liturgical Sacrifice can be celebrated or to whom the special effects of the liturgy can be applied (no.11), the duty of the priest to celebrate and for whom he can celebrate, as well as the significance and the limits of the liturgicaly stipends (no.12), and a series of measures against the possible abuses in practice (no.13)

In comparison with the description of the Holy Liturgy as centre of the public cult, emphasized in CP III, we find it useful to include the content of the 698 canon from CCEO, with which starts Chapter III - De cultu divino et praesertim de sacramentis: "In Divinam Liturgia, per ministerium sacerdotis in persona Christi super oblationem Ecclesiae agentis perpetuatur virtute Spiritus Sancti, quod ipse fecit in novissima Cena Dominus Jesus, qui discipulis dedit Corpus Suum in Cruce pro nobis offerendum Sanguinemque Suum pro nobis effundendum, verum mysticumque instaurans sacrificium, quo cruentum illud Crucis sacrificium cum gratiarum actione commemoratur, actuatur et ab Ecclesia participatur tum oblatione tum communione ad significandam et perficiendam unitatem populi Dei in aedificationem Corporis Sui, quod est Ecclesia".

We underline, through a comparison of the two pieces of text, the final term of the eucharistic liturgical act:

\begin{tabular}{||c||l||}
\hline \multicolumn{1}{|c|}{ CP III (CP I): } & \multicolumn{1}{|c|}{ CCEO: } \\
\hline \hline $\begin{array}{l}\text { Pro peccatis, poenis, satisfactionibus } \\
\text { et aliis necessitatibus }\end{array}$ & $\begin{array}{l}\text { ad significandam et perficiendam } \\
\text { unitatem populi Dei in aedificationem } \\
\text { Corporis Sui, quod est Ecclesia }\end{array}$ \\
\hline
\end{tabular}

Together with the observation made above, the two texts present theological options or perspectives that, if we give credit to the Lex Magister est principle, mark in a more or less conscious way, the pastoral, catechetic activity contiguous to the cultic and liturgical activity. From a theological perspective, the ideas included in the first text can be integrated into the second one as well. However, since our Church has only recently been able to resume the normal course of its activity, the reconnection to the options of the Second Vatican Council is essential, options that were reiterated in the canons of the new Code for the Oriental Churches. According to the Constitution related to the liturgy, Sacrosactum concilium, the liturgical celebrations should be characterised

\footnotetext{
${ }^{9}$ Ibidem, p.94.
} 
by a noble simplicity and clarity. ${ }^{10}$ Extending this to the activity of codification, at least as far as the cultic-sacramental aspects are concerned, the new code may be said to have translated this clarity in the expressive character of the language of the liturgical experience. With the view of making a coherent and homogeneous actualisation of the particular law in accordance with "The directives for the application of liturgical norms of the Code of the Oriental Churches Canons", emitted by the Congregation for the Oriental Churches, we believe that an objective analysis of our current situation, with all its historical conditionings, is crucial.

With this purpose in mind, we shall try to present the background for the theological thought in cultic and sacramental matters, as it emerged in the $17^{\text {th }}$ and the $18^{\text {th }}$ centuries, with a special attention given to the balance between theory and practice (liturgical and sacramental). In the above-mentioned centuries, three traditional confessions were represented in Transylvania, so it can be easily inferred that that balance we have just referred to was rarely in a state of equilibrium.

\section{The echoes of Protestant reformers' theses on sacramental matters in the Orthodox world ${ }^{11}$}

From the sixteenth to the eighteen century, the ideal of "spreading Christianity" was common to both the Protestant and the Catholic parts of the world, a fact that contradicts the legend of the existence of the Christian Middle Ages, and is more and more confirmed by the "new history" that focuses upon the "mentalities" of the period under scrutiny ${ }^{12}$. On both sides, the attempt at reformation was meant to cleanse Christianity of any trace of magic-animistic influences related to superstition, in order to preserve exclusively the essential nature of Christianity. For this reason, it might be wrong to restrict the inter-religious disputes of the epoch only to some interests of a social or political nature, or simply to a confessional proselytism in itself, though these factors, and probably many others, have had their contribution at some points. We could resume by saying that the period was marked by the reformation of Christianity as external, social reality, which, nevertheless, remained to spiritualised.

The attempts to attract the Orthodox hierarchs on the side of the protestant reform started in 1559, when Melanton sent Ioasaf, the Patriarch of Constantinople, a Greek translation of the Augsburg Confession, which has, nevertheless, received no answer. Intermittently, such attempts continued in

\footnotetext{
${ }^{10}$ Cf. SC, 34.

${ }^{11}$ About this idea in the Greek and Slavonic Orthodoxy, a relatively extensive study can be found in R. Hotz, Los sacramentos en nuevas persepctivas. La riqueza sacramental de oriente y occidente [translated by B. Girbau according Sakramente im Wechselspiel zwischen Öst und West, Köln 1979], Salamanca 1986, p. 131-203.

${ }^{12}$ Cf. J. Delumeau, Le catholicisme entre Luther et Voltaire, Paris 1971.
} 
the subsequent decades, making use of Western diplomatic structures, favourable to the Reform, ubiquitous throughout the Ottoman Empire.

With these initial contacts, the Orthodox part could remark the absence of a systematic reflection upon the sacraments, which might have given a clear answer to the assumptions of the Protestant theologians. An exception is represented by a compendium on the Holy Seven Sacraments, entitled Syntagmation peri tôn 'agiôn kai 'ieron mysteriôn, edited in Venice by Gabriel Sevęros, archbishop of Philadelphia and archpriest of the Orthodox Church in Venice. The work, comprising two volumes, represents a mediocre compilation of scholastic doctrinarian opinions, emphasizing the elements of controversy with the Latins. ${ }^{13}$

This deficiency became more acutely felt when a Patriarch of Constantinople - Kyril V (Loukaris), patriarch between 1620-1635 and 1637-1638 - installed with the help of the Dutch ambassadors at the Ottoman Port, started to openly support Calvinist theses, going as far as publishing an Confession of Calvinist belief in Geneve, $1629^{14}$.

A response with a theological basis came only in 1640 from the archbishop of Kiev, Petru Movila, the son of Moldavia's voivode, who had studied theology in Lemberg (Lwiv), a place of contact between the Orthodox and the Catholics in Ukraine, after the partial union from BrestLitovsk in 1595. It seems that Petru Movila might have studied at Sorbone as well. For these reasons, he must have been familiar with the RomanCatholic trains of thought, which might explain the publication in Latin of a Confessio fidei orthodoxa, that was discussed by a regional synod held in Kiev in the same year, though without any point of agreement having been reached. At the insistence of the archbishop mentioned above and with the support of Vasile Lupu, the voivode of Moldavia, the Patriarch of Constantinople, Parthenios I, has summoned a synod in Iasi in 1642, where delegates of the Greek and the Russian patriarchs have participated. A revised and translated (in Greek) edition of Movila's Confession (this time entitled Orthodoxos homologia ${ }^{15}$ ) was presented and, in the next year, that piece of writing received the official assent of the four Greek patriarchs.

A synod held in Jerusalem in 1672 ratified again the Orthodoxos bomologia, to which a second part, consisting of a confession of faith by the Patriarch of Jerusalem, Dositei II (Notaras), and entitled Aspis

\footnotetext{
${ }^{13}$ Cf. R. Hotz, op.cit., p.135, note 8.

${ }^{14}$ In a more concise, and presented from an orthodox perspective, though not substntially different, the text can be read in H. Andruțos, Simbolica, translated by Iustin Moisescu, Patriarch of the Romanian Orthodox Church, after the original Greek edition from 1930), Editura Anastasia, Bucuresti, 2003, p.55-56.

15 The official Greek document Orthodoxos homologia tęs pistęos tes katolikes kai apostolikęs ekklęsias tęs anatolikęs, publicat în I. Mihălcescu, Thęsauros tęs orthodoxias: Die Bekenntnisse und wichtigsten Glaubenzeugnisse der griechisch-orientalischen Kirche im Originaltext, nebst einleitenden Bemerkungen, Leipzig 1904, p. 29-122.
} 
orthodoxias (=The defence of Orthodoxy)- had been added. It was meant as an orthodox answer to the theses of Kyril Loukaris, corresponding to those in terms of theme and structure.

In 1685, Joachim (Savelov), the Patriarch of Moscow, demanded that the orthodox Confession published at Iasi should be translated into Slavonic. The patriarch's successor, Adrian, came to appreciate that book as a work inspired by God.

In that way, the orthodoxy started to assume a doctrine of the sacraments of an undoubtedly Latin, scholastic, inspiration, in spite of the strong anti-Roman feelings that dominated it at certain moments in time. For instance, the above-mentioned Patriarch of Jerusalem, Dositei II, though more openly against Rome than his colleagues from Constantinople, accepted the doctrine of the trans-substantiation. Or, in the Slavonic world, a theological school with a catholic orientation, following the scholastic method of Toma d'Aquino, functioned in Kiev in the seventeenth century. In the first half of the eighteenth century, with the support of the Czar Petru I, a school with a protestant orientation was founded. However, there was another school in Moscow, which was closer to the Greek tradition and managed to become more prominent than the school in Kiev. For all that, up until the nineteenth century, the Russian orthodoxy continued to be firm as far as the general doctrine of the sacraments, of a catholic influence, was concerned. From that moment on, in the context of a pro-Slavonic movement, a return to the eastern tradition was initiated.

Within the more conservative Greek theological world, in spite of the feelings against Rome, a general doctrine of the sacraments, of catholic inspiration, was maintained.

In terms of the theme of the sacraments, starting with the seventeenth century, a common attitude on the part of the orthodoxy in general had emerged: each of the sacraments ware perceived and interpreted from a neo-Platonic perspective, while the seven sacraments on the whole, as well as the treaty about the sacraments in general, were constructed on an Aristotelian basis. This scholastic-Aristotelian superstructure would not manage to penetrate very deeply the popular consciousness of the majority of the clergy, being restricted to only few theological centres. ${ }^{16}$

In the seventeenth century, as it is well known, the reformed-calvinist pressure was not merely tangential for the Orthodox Church in Transylvania, its promoters benefiting from social and political support and being able to exert influence. In order to briefly present the situation in this region in the sixteenth, the seventeenth and the eighteenth centuries, we shall quote from a relatively recent study, although the appreciation seems to be rather too optimistic or generalised: "The Romanian church in Transylvania should be appreciated as a reformed and modernized

\footnotetext{
${ }^{16}$ Cf. R. Hotz, o.c., p.139.
} 
Orthodox church, a change that was determined, among other factors, by some protestant principles and by the special political context in which the Orthodoxy had to function under the Habsburg dominance, many centuries before the beginning of the Reform. At the same time, the assertions of the historians belonging to the structures of the Orthodox Church, stating that the Reform did not penetrate too profoundly into the Romanian world, the dogmatic ignorance of both the clergy and the believers representing a strong enough obstacle in front of the heresy of the new teachings, are still valid. There are, nevertheless, those statements that assimilate the Calvinian influence in the administering of the sacraments with the negligence and the insufficient education of the clergy in matters of Christianity, that remain outside the historical truth. A similar inadequacy in terms of historical truth is presented by the opinions according to which the whole Transylvanian scholarly activity might have had the same Romanian composition even outside the dialogue with the Reform, as well as the view that the Romanian language had been used in the cultic activities in the XVI-XVII centuries as the result of a single internal need of the Romanian orthodoxy."17

\section{The sacramental theology in ratio studiomum of the Jesuit order}

As a measure in the line of the Catholic Reform or the counterReform, a large number of the seminaries or universities from the areas dominated by the Habsburg Empire were committed to the directorial board of the members of the Jesus Society, which contributed at the strong reaction against that order and its eventual banishment by Pope Clement XIV in 1773 , only to be fully reinstated in 1814 . It is well known that the members of that order would often represent the avant-garde of catholic missions, as it happened in Transylvania. The theological formation provided by that school to the first theologians of the Greek-Catholic Church in Transylvania determines us to focus on it more extensively. ${ }^{18}$

During the eighteenth century the ratio studiorum, set up by General Claudio Acquaviva in 1599, was still in force, and to it a series of norms referring to the exams in theology and philosophy had been subsequently added (as a result of the decisions made at the seventh General Congregation in 1615-1616). The formative ideal of that ratio was summarised by G. Filograssi in the following way: "1. The programs and the methods have a predominantly formative form, since both the vastness of erudition and the

\footnotetext{
17 A. Dumitran - G. Botond - N. Dănilă, Relații interconfesionale româno-maghiare în Transilvania (mijlocul secolului XVI - primele decenii ale secolului XVIII). Román-magyar felekezetközi kapcsolatok Erdélyben (a XVI. század közepe - a XVIII. század elsó évtizedei között) [col. "Bibliotheca Musei Apulensis", XIII], Alba Iulia 2000, p. 128.

${ }^{18}$ Cf. X. Le Bachelet - J. de Blic - P. Bouvier, art. Jésuites (La Théologie dans l'ordre des), în DThC VIII, 1012-1108; pentru secolul al XVIII-lea, col. 1043. 1050-1052; G. Filograssi, La Teologia dogmatica nella "Ratio studiorum" della Compagnia di Gesù e le scienze sacre, în La compagnia di Gesi e le scienze sacre, Romae 1942, p. 13-44; S. Ubbiali, Il Segno Sacro. Teologia e sacramentaria nella dogmatica del secolo XVIII, Glossa, Milano 1992, p. 46-62.
} 
depth of assimilation are pursued. The scholastic method is wonderfully appropriate to our purpose: the truths presented at school, assimilated more profoundly while studying in private, revised and repeated, discussed and disputed, are assimilated by the mind and they ensure a form and a configuration through which the learner is further enabled to become agile in the presentation of new notions and ideas, and weigh the value of assertions and demonstrations, detect the weaker points of counterarguments, and subtly descern the thruth from false assumptions. 2. The teachers will be prepared from a spiritual, scientific and pedagogical point of view; the students will be familiarised yet with spiritual, literary and philosophical ideas. 3 The schedule illustrates exactly the existance of a single Doctor, Saint Thomas, a unique book, Summa Theologiae. A well organised group of lessons, repetitions, debates, should converge towards a clear and precise purpose: Sacra Teologia. The professor has to enliven the development of the courses, while both he and the student actively and intensy participate to the class. 5. The governing of the studies and of the schools should be unitary and well-organised. 6 . The formation acquired in this way represents, as demonstrated previously, an excellent basis for the fruitful cultivation of positive sciences. Moreover, we are allowed to say that, in the first century of our Society, the methods and the schedules of this Ratio have managed to form ilustrious persons, who contributed to the fundamentation of positive ecclesiastical sciences." ${ }^{19}$ However, the basic text of study, represented by the thomist systemisation, was not merely immitated: the commentaries upon the thomist quaestiones, turned into disputationes, gradually abandoned the criteria of thomist systemisation, adopting others in accordance with the new preoccupations. It was the case of Roberto Bellarmino who, in De Controversiis Christianae Fidei adversus hujus temporis haereticos, a course presented at the Roman College between 1576 and 1588, and later published in three volumes (1586-1593), organised the subjects in four parts: "the rules of faith” (De Verbo Dei scripto et non scripto; De Christo capite totius Ecclesiae; De summo Pontifice capite militantis Ecclesiae), the Church, the sacraments and the grace. ${ }^{20}$ His innitiative was quickly accepted and reproduced, disregarding however the circumstances that justified the type of work he had intended to write.

Other authors continued to obey the succession of the articles of the thomist Summa, with an insertion towards the end of the analysis of some comments, questions (or dubia) that later became real authentic dissertations based on singular theological arguments. The common element in this diversity of approaches ${ }^{21}$ is represented by the constant

\footnotetext{
${ }^{19}$ Cf. G. Filograssi, op. cit., p. 27.

${ }^{20}$ Cf. X. Le Bechelet, art. Bellarmin, în DThC II/1, 597-598.

${ }^{21}$ Cf. S. Ubbiali, op. cit., p. 48-49.
} 
reference made to the text written by Francisco Suárez (1548-1617) whose disputationes comment upon the tomist text. ${ }^{22}$

With reference to the work of Suárez and the preoccupations of our article, it might be interesting to point out in Disputatio XV - De sacramentalibus, seu caeremoniis sacramentorum in genere, more exactly in association to the relationship between the cultic-ritual and the sacramental aspects, that the discussion on this point is an additional comparative comment in relation to the thomist summa ${ }^{23}$, though the following were immediately added: "tamen, cum in singulis sacramentis, de uniuscujusque caeremoniis disserandum sit cum ipsemet D. Thoma, necessarium visum est, hoc loco praemittere ea, quae communia ac generalia esse possunt, ${ }^{24}$. Without insisting on the details of the argumentation, we could mention at least the titles of the four sections, which are suggestive enough in order to emphasize the principle that lies at the basis of the problematization: I. Quid sit caeremonia seu sacramentale; II. An usus sacramentalium religiosus et sanctus sit atque Ecclesiae conveniens; III. Quis possit sacramentales caeremonias instituere, mutare aut ministrare; IV. Utrum haec sacramentalia habeant aliquem effectum spiritualem; a perspective that, through the illustration of the difference between ceremony and sacrament, underlines the value of locus theologicus of the liturgy in the penumbra cone placed by the scholastic conceptualization of the sacrament in re.

In fact, this view might have been suggested by Toma d'Aquino himself through the distinction he made between sacrament and sacrifice in the case of the Eucharist, in STh III, q.79 (De effectibus buius sacramenti [Eucharistiae]), a.5 sii a.7. In the 5th article, answering the question utrum per hoc sacramentum tota poena peccati remittatur, the author maintains that this sacrament is at the same time sacrifice and sacrament, but has the aspect of assumed and received sacrament, and for this reason, the effect of sacrament is received by the one who receives it, while the effect of sacrifice is associated with the one who offers it or the one for whom it is offered. Then the effects of the Eucharist are analysed, the latter being considered under its two main aspects in order to answer the innitial question and objections.

Under the sacramental aspect, a double effect can be mentioned: first, the direct ex vi sacramenti, by virtue of which the sacrament has, in a

\footnotetext{
${ }^{22}$ Jacques de Blic describes the second century in the existence of the Society with reference to the theological aspect, and in relation to the first century, this second one being described as a period of mere assimilation of the work conducted so far, and of popularization: cf. Art. Jésuites, DThC VIII, 1050-1051.

23 "Haec disputationem praetermisit D. Thomas in hac materia": Franciscus Suarez, Opera omnia, vol. XX (Commentaria ac disputationes in tertiam partem D. Thomae, de Sacramentis in genere, de Baptismo, de Confirmatione, de Eucharistia usque ad q. LXXIV), Parisiis 1860 , p. 283.

${ }^{24}$ Ibidem.
} 
direct way, the effect for which it has been instituted - non ad satisfaciendum, se ad spiritualiter nutriendum per unionem ad Christum et ad membra eius, the union which is achieved through charity, out of whose fervour the human being obtains the absolution from both sin and punishment; from this, and as a result of the first effect, follows the second way in which the effect of the Eucharist, under the aspect of sacrament emerges, quasi ex quadam concomitantia, through which the human being obtains the absolution from punishment, non quidem totius, sed secundum suae devotionis et fervoris.

Under the aspect of sacrifice, it has a vim satisfactivam meaning. What is rather expected is the devotion of the person who offers, rather than the quantity of the offer (here the example of the two silver coins of widow Luke, 21,4 - is given). In terms of the quality of the offer given with the Eucharist, this is sufficient for the abolition of any punishment, but in relation to the one who offers it, or the person for whom it is offered, the quantity of its devotion might be different.

The distinction between sacramentum and sacrificium is further discussed in the seventh article of the same question, in order to answer the question whether this sacrament is useful to more than those for whom it is meant; for these, qui non sumunt [Eucharistiam], prodest per modum sacrificii, using as argument the fragment from the Roman Canon: Memento Domine, famulorum falumarumque tuarum, pro quibus tibi offerimus, vel qui tibi offerunt...

From the contents of the same Summae Theologiae, we can mention the ideas discussed in the 83 problem, entitled De ritu buius sacramenti, which questions in the first article the problem of utrum in celebratione buius sacramenti Christus immoletur which, under its different form, discusses again the sacrifical aspect of the Eucharist.

We close here the parantheses opened with this digression into the XIIIth century and the work of Toma d'Aquino, and return to Francisco Suárez because in his extensive commentary on the thomist summa from this point starts the treatise de Missae Sacrifficio ${ }^{25}$, organised into seven disputationes (from 83-88), following the discussion of De Sacramento Eucharistiae secundum se (disputationes $73-82)^{26}$ which was started by the very commentary on this article of Saint Thomas. In its introduction, as in the case of disputationis $X V$, it is mentioned the fact that, if in the first aspect of the mistery of the Eucharist, ratione sacramenti saint Thomas had treated ex professo, for the second aspect, ratione sacrificii, he had done it quasi incidenter et brevissime. ${ }^{27}$ We will not discuss here the content of the treatise mentioned above, or try to appreciate the

\footnotetext{
${ }^{25}$ F. Suárez, op. cit., vol XXI, p. 599-951.

${ }^{26}$ Ibidem, din vol. XX, p. 700, până în vol. XXI, p. 598.

${ }^{27}$ Ibidem, vol. XXI, p. 599.
} 
systemisation put forward by Suárez, which were relevant only to that particular historical and inter-religious context.

\section{Conclusions}

In conclusion we would like to emphasize the influence that such a systemisation, specific to a theological school ${ }^{28}$, has, in time, an important impact on the perception of the sacramentall act, as it is presented in obliquum in the texts of our regional synods and their fundamental assertions on cultic and sacramental matters. A one-sided, individualistic perspective on the benefits of the sacraments, which collateraly leads towards a separation between sacrament and its celebration or, in a broader sense and using the manualistic language typical to that current, the separation of "the usage of the sacraments" from the liturgical celebration (e.m). In this respect, the new CCEO, at least in its XVI Title, may be regarded as an invitation to reconsider the value of the liturgical experience in the expression of theological contents.

\footnotetext{
${ }^{28}$ In this line we could rank a manualistic tradition that continued up until ther first half of the 20th century, which may be associated with the work of H. Noldin, Summa Theologiae moralis. III: De Sacramentis, editia a 13-a, Oeniponte, 1920, extensively used in our seminaries in the inter-war period.
} 